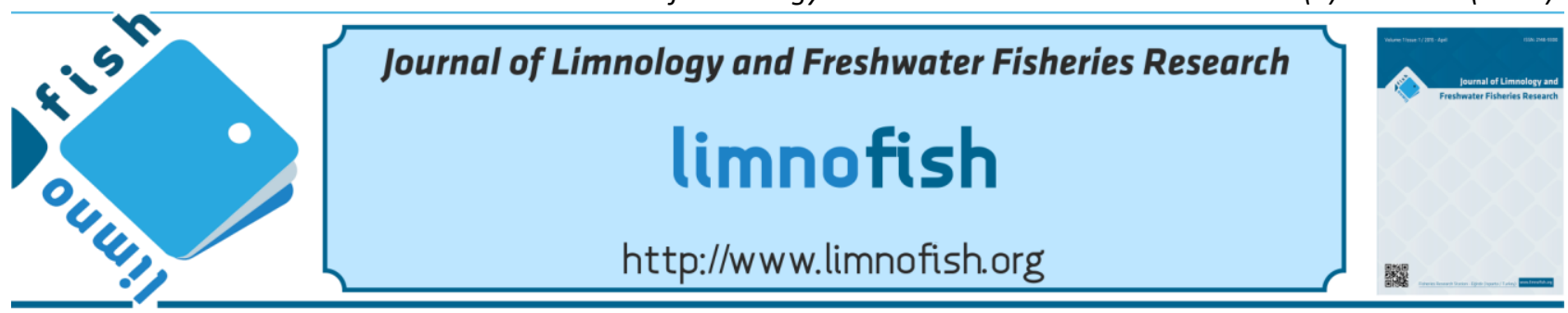

\title{
Growth Performance and Substrate Preference of Juvenile Mexican Dwarf Orange Crayfish (Cambarellus patzcuarensis) in Different Substrate Types
}

\author{
Onur KARADAL ${ }^{1 *}$ iD, Gürel TÜRKMEN² \\ ${ }^{1}$ Department of Aquaculture, Armutlu Vocational School, Yalova University, 77500, Armutlu, Yalova, Turkey \\ ${ }^{2}$ Department of Aquaculture, Faculty of Fisheries, Ege University, 35100, Bornova, İzmir, Turkey
}

\begin{abstract}
A B STRACT
Substrate is very important factor on growth and survival for crayfish in their entire life. Survival rate and growth of juveniles of the Mexican dwarf orange crayfish (Cambarellus patzcuarensis) were evaluated in aquaria with six different substrates covering their bottom. The six different substrates were plastic mesh, pebble, sand, basalt and calcite and bare glass without a cover as a control group. The study was carried out in two different experimental areas. In the first experiment, ten (mean body weight $0.25 \pm 0.01 \mathrm{~g}$ ) juveniles were stocked in aquaria with above mentioned six substrates and each substrate in three replicates. After 100 days, the best weight gain was observed in the group raised on basalt substrate $(\mathrm{P}<0.05)$. In the second experiment, juveniles were individually placed in a hexagonal glass aquarium divided into six sections each containing one of the same substrates used in the first experiment was used for substrate preference. Each individual was filmed for $24 \mathrm{~h}$, and the time spent in each compartment was registered. Basalt was the most preferred substrate for Mexican dwarf orange crayfish $(\mathrm{P}<0.05)$. The preference of basalt substrate can be explained by its proximity to the natural substrate of this species.
\end{abstract}

Keywords: Cambaridae, habitat variation, growth, survival, pet trade.

\section{ARTICLE INFO \\ RESEARCH ARTICLE

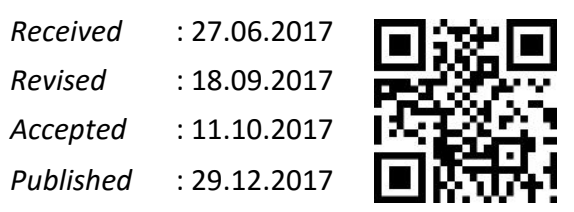

DOI: 10.17216/LimnoFish.323764

\section{* CORRESPONDING AUTHOR}

onurkaradal@yalova.edu.tr

Phone:+90 2268155435

Farklı Substrat Tiplerinde Genç Meksika Cüce Portakal Kerevitlerinin (Cambarellus patzcuarensis) Büyüme Performansı ve Substrat Seçimi

Öz: Substrat, kerevitlerin yaşamlarının tüm evrelerinde büyüme ve yaşama oranı açısından oldukça önemli bir faktördür. Jüvenil Meksika cüce portakal kerevitlerinin (Cambarellus patzcuarensis) yaşama oranları ve büyümeleri, zemininde altı farklı substrat bulunan akvaryumlarda incelenmiştir. Substratlar sinek teli, çakıl, kum, basalt, kalsit ve kontrol grubu olarak ta boş cam şeklinde belirlenmiştir. Çalışma iki farklı deneme ortamında yürütülmüştür. İlk denemede yukarıda bahsedilen altı substrat bulunan

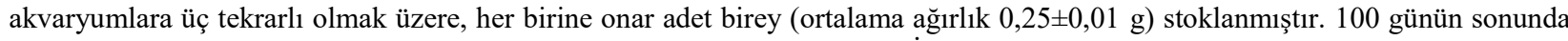
en iyi ağırlık artışı, bazalt üzerinde beslenen grupta gözlenmiştir $(\mathrm{P}<0,05)$. İkinci denemede, substrat seçimi için jüveniller, tabanı altıya bölünmüş ve her bir bölümde ilk denemeyle aynı substratlar bulunan altıgen şeklindeki bir akvaryuma bireysel olarak stoklanmıștır. Kerevitlerin her biri 24 saat izlenmiș ve her bölümde geçirilen süreler kaydedilmiștir. Bazalt, Meksika cüce portakal kerevitleri için en çok tercih edilen substrat olarak bulunmuştur $(\mathrm{P}<0,05)$. Bu substrat türünün sıklıkla tercih edilmesi, türün doğal substratına yakınlığı ile açıklanabilir.

Anahtar kelimeler: Cambaridae, habitat değişimi, büyüme, yaşama oranı, evcil hayvan ticareti.

\section{How to Cite}

Karadal O, Türkmen G. 2017. Growth Performance and Substrate Preference of Juvenile Mexican Dwarf Orange Crayfish (Camberellus patzcuarensis) in Different Substrate Types. LimnoFish. 3(3):167-173. doi: 10.17216/LimnoFish.323764

\section{Introduction}

Nowadays, aquaristic is a popular hobby of millions supporters worldwide. In the United States, 95.5 million freshwater fish and 9.5 million marine fish are reported to be handled in aquariums in 2016 (APPA 2016). It is also indicated that there are 36 million aquarium fish as a result of surveys conducted with 4,000 people in England (PFMA 2016).

A wide range of freshwater invertebrates are also kept in captivity (Chucholl 2013; Patoka et al. 2014). Alternative species are being introduced to aquarium sector speedily, including freshwater decapods such as shrimps, crayfish and crabs (Faulkes 2015; 
Patoka et al. 2015). The interest in crayfish is increasing even though shrimps have seen more popular among these living groups (Türkmen and Karadal 2012a). Aquarists interest in crayfish species for many causes such as their interesting behaviours, individual personalities, attractive colours and patterns. Therefore, mostly exotic crayfish species are favoured for home aquariums, including Cherax quadricarinatus, C. destructor, C. cainii, C. peknyi, C. gherardiae, C. holthuisi, Cambarellus patzcuarensis, Procambarus clarkii, P. alleni (Kawai et al. 2015) and many others, also they are becoming more commonly seen for sale in aquarium stores and websites (Türkmen and Karadal 2015).

The global achievement of the freshwater crayfish farming in recent years is based on the selection of species with sufficient characteristics for both cultural and commercial purposes (Viau and Rodríguez 2010). Healthy and peaceful crayfish species are preferred for ornamental purposes by skilled aquarists. Species found in the aquarium trade include many crayfish species from Parastacidae and Cambaridae family, including Mexican dwarf orange crayfish, C. patzcuarensis (Kwang et al. 2010). C. patzcuarensis comes from Lake Pátzcuaro, a volcanic crater lake in Michoacán which is located in southwest of the major city of Morelia, Mexico. Wild individuals of this crayfish are mostly tan, brown, and rust colour (Pottern 2007). However, the orange colour morph of the dwarf species originated in the Netherlands (Dost 2013). Mexican dwarf orange crayfish is suitable for smaller sized aquaria (attaining a maximum length of $4 \mathrm{~cm}$ ). Unlike most crayfish, this species does not destroy plants because of their peaceful nature (Rohmann 2010). $C$. patzcuarensis is not only sold in Turkey, but is an extremely common pet in other countries, including the United States (Faulkes 2015), the United Kingdom (Peay et al. 2010), Germany (Chucholl 2013), Greece (Papavlasopoulou et al. 2014), the Czech Republic (Patoka et al. 2014), and Slovakia (Lipták and Vitázková 2015). Further, this species is listed on the IUCN red list of endangered species (Alvarez et al. 2010). Like many crayfish, this species exhibits mortalities during juvenile stages because of some reasons, including vulnerability in the moulting process and cannibalism. However, crayfish need substrate or shelters for providing themselves from external dangers.

Substrate type is important to stream communities (Francis and Kane 1995). Many decapod groups such as shrimps, crabs and crayfish are existed in the bottom of both lotic and lentic areas in inland waters (Zimmermann et al. 2016). These macroinvertebrates have some unique features such as tail flipping, punting and digging (Faulkes 2006).
Bottom substrate of aquaria has been mixed by digging behaviours of crayfish and this causes the cycling of detritus. For this feature, crayfish are naturally considered keystone organisms to the ecological habitats (Kusabs et al. 2015). Although freshwater decapods are important organisms for inland streams, limited information is known about their substrate requirements in artificial environments.

Although Mexican dwarf orange crayfish is an important species for aquarium trade, there are no studies on their culture, growth and survival or substrate requirements. In the present study, effects of six different substrates on growth and survival of juvenile Mexican dwarf orange crayfish were investigated and their substrate preference was observed. The aim of these experiments was to test whether natural substrate of Mexican dwarf orange crayfish is important for its culture.

\section{Materials and Methods \\ Rearing system and crayfish}

The experiment was carried out in eighteen glass aquaria $\left(1000 \mathrm{~cm}^{2}\right.$ of bottom surface) at a density of 10 crayfish per tank with three replicates for each substrate type. Each aquarium contained 2-cmdiameter PVC pipes in excess as refuge. Temperature was maintained at $24.5 \pm 0.7^{\circ} \mathrm{C}$, and photoperiod was held at 14:10 (light/dark). The water in all aquaria was changed twice a week. Dissolved oxygen (WTW-Oxi 315), pH (Sartorius PT-10), ammonia (HANNA C205), total hardness (measured with Aquamerck ${ }^{\circledR}$ kit, 114652 total hardness test) and alkalinity (measured with Aquamerck ${ }^{\circledR}$ kit, 111109 alkalinity test) were determined in each aquarium at the beginning and at the end of the experiment before changing water and feeding the animals. Juveniles $(0.25 \pm 0.01 \mathrm{~g}$ of body weight $)$ of Mexican dwarf orange crayfish, $C$. patzcuarensis were used in this study. Crayfish were provided from a commercial facility in Antalya, Turkey, and transported to the Faculty of Fisheries, Ege University, Turkey. Prior to the start of the feeding trial, crayfish were transferred to non-substrated aquariums for 1 week for acclimation. Every day, all animals were fed near to satiation with commercial feed (Ecobio $\left.{ }^{\circledR}\right) 1.5 \mathrm{~mm}$ granules, $44 \%$ of protein) during the experiment.

\section{Experimental design and substrate types}

Six different substrates were tested in this study. Bare glass is non-substrated control group. Plastic mesh is similar to mosquito netting adhered to the bottom of the aquarium. Particle sizes of other substrates for pebble is $3-5 \mathrm{~mm}$, sand is $800-1000$ $\mu \mathrm{m}$, calcite is $800-1000 \mu \mathrm{m}$ with white colour and basalt is $300-500 \mu \mathrm{m}$ with greyish black colour. 
Particulates substrates (pebble, sand, basalt and calcite) covered the bottom of aquaria in the layer of $0.5 \mathrm{~cm}$.

\section{Evaluation of growth performance}

Ten juveniles were placed in each aquarium, similar to densities used previous research carried out by Viau and Rodríguez (2010) with early juveniles of Australian red claw crayfish, C. quadricarinatus. Total length and weight measurements were carried out biweekly during 100-days experiment. All animals were dried with a paper towel to remove excess water before measurement process. Crayfish weights were individually measured with an electronic balance (Sartorius BL610, precision of $\pm 0.01 \mathrm{~g}$ ) and total lengths were measured with vernier caliper.

\section{Substrate preference}

In the substrate preference experiment, a hexagonal glass aquarium $(60 \mathrm{~cm}$ of length of diagonal filled with $7 \mathrm{~L}$ of dechlorinated water) divided on the bottom into six equal sections each containing a different substrate. The substrates tested were the same substrates used in the growth performance experiment. Ten individuals of $0.25 \mathrm{~g}$ from the first experiment were tested and each individual was recorded for $24 \mathrm{~h}$ and the time spent in each compartment was assessed from recording. In the beginning of the video recording, each crayfish was placed in the center of the hexagonal aquarium. The movement of each juvenile in the experimental arena was recorded with a web camera (Piranha Tarantula) located directly above the center of the aquarium and connected to a PC (Figure 1). The experimental arena was placed in a closed room maintained at an ambient temperature of $24.4 \pm 0.6^{\circ} \mathrm{C}$ and a 14:10 (light/dark) photoperiod. During the light phase, the light source was a white lamp located above the aquarium and connected to a timer. During the dark phase, the light source was infrared LEDs located around the webcam. Animals were not fed during the experiment. The time spent in each substrate during the $24 \mathrm{~h}$ recording was calculated for each animal.

\section{Statistical analysis}

All data sets were examined to verify normality, independence and homogeneity of variance before further analysis was undertaken. All data were subjected to one-way analysis of variance (ANOVA) when interaction between the factors is found differences, Duncan's multiple range test was used to rank groups using SPSS 15.0 (SPSS Inc., Chicago, Illinois, USA) statistical software (Zar 2001). All data are presented as mean \pm standard error of the mean calculated from all replicates. In all tests, a significance level of $\mathrm{P}<0.05$ was used.

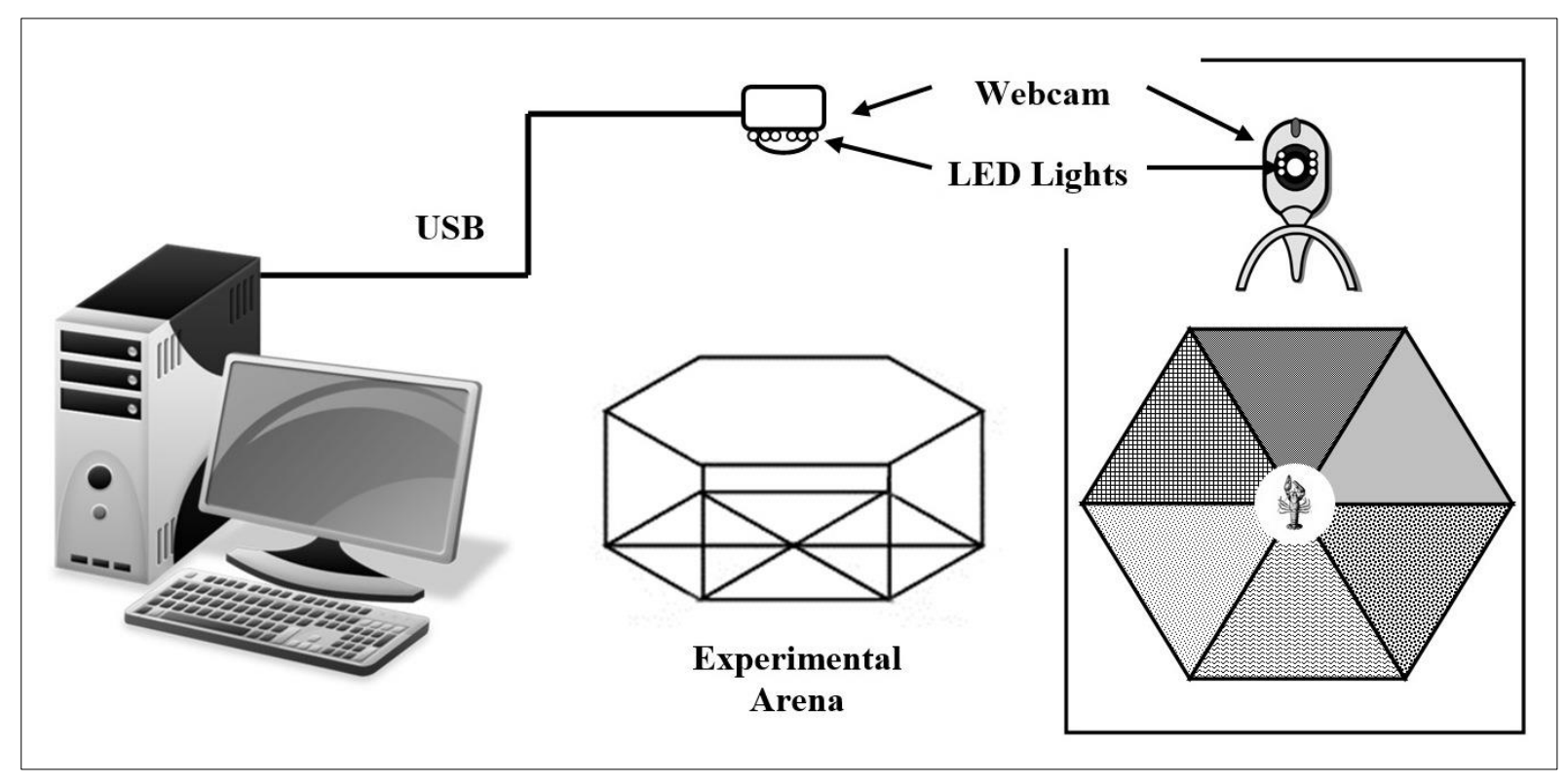

Figure 1. Scheme of the experimental area used for the substrate preference experiment

\section{Results}

The growth performance of Mexican dwarf orange crayfish kept in different substrates was given in Table 1. The final mean weight $(F M W)$ of juveniles raised on the basalt substrate was significantly higher $(\mathrm{P}<0.05)$ than those all other substrates. Bare glass (control) was the lowest among the other substrates, except calcite $(\mathrm{P}<0.05)$. Pebble and sand groups were significantly higher than plastic mesh group which substrates causing intermediate effect for $F M W(\mathrm{P}<0.05)$. Differences among mean weights (final ranges for bare glass was 
$0.39 \pm 0.01 \mathrm{~g}$ and basalt was $0.53 \pm 0.01 \mathrm{~g}$ ) emerged after 60 days (Figure 2). Enhancing of average total lengths $(\mathrm{cm})$ of Mexican dwarf orange crayfish kept in different substrate types during 100-days was shown in Figure 3. The final mean total length
(FMTL) of basalt and pebble groups were statistically greater than bare glass and calcite groups $(\mathrm{P}<0.05)$. There were no significant differences in carapace lengths. The survival rate was $100 \%$ in this study because of no animals died during the study period.

Table 1. Growth performance of Mexican dwarf orange crayfish after 100 days of substrate experiment $(n=3)$

\begin{tabular}{lcccccc}
\hline Parameter & Bare glass & Fly mesh & Calcite & Sand & Pebble & Basalt \\
\hline Initial mean weight $(\mathrm{g})$ & $0.25 \pm 0.01$ & $0.25 \pm 0.01$ & $0.24 \pm 0.01$ & $0.25 \pm 0.01$ & $0.25 \pm 0.01$ & $0.25 \pm 0.01$ \\
Final mean weight $(\mathrm{g})$ & $0.39 \pm 0.01^{\mathrm{a}}$ & $0.43 \pm 0.01^{\mathrm{b}}$ & $0.41 \pm 0.01^{\mathrm{ab}}$ & $0.46 \pm 0.01^{\mathrm{c}}$ & $0.49 \pm 0.01^{\mathrm{c}}$ & $0.53 \pm 0.01^{\mathrm{d}}$ \\
Initial mean total length $(\mathrm{cm})$ & $2.12 \pm 0.03$ & $2.12 \pm 0.03$ & $2.11 \pm 0.03$ & $2.12 \pm 0.03$ & $2.12 \pm 0.03$ & $2.12 \pm 0.03$ \\
Final mean total length $(\mathrm{cm})$ & $2.45 \pm 0.02^{\mathrm{a}}$ & $2.50 \pm 0.03^{\mathrm{ab}}$ & $2.47 \pm 0.03^{\mathrm{a}}$ & $2.52 \pm 0.03^{\mathrm{ab}}$ & $2.55 \pm 0.02^{\mathrm{b}}$ & $2.58 \pm 0.03^{\mathrm{b}}$ \\
Initial mean carapace length $(\mathrm{cm})$ & $0.73 \pm 0.01$ & $0.73 \pm 0.01$ & $0.72 \pm 0.01$ & $0.73 \pm 0.01$ & $0.73 \pm 0.01$ & $0.73 \pm 0.01$ \\
Final mean carapace length $(\mathrm{cm})$ & $0.91 \pm 0.05$ & $0.88 \pm 0.01$ & $0.86 \pm 0.01$ & $0.88 \pm 0.01$ & $0.89 \pm 0.01$ & $0.90 \pm 0.01$ \\
\hline
\end{tabular}

The water quality parameters did not change significantly $(\mathrm{P}<0.05)$ among treatments. The mean value of $\mathrm{pH}$ was $7.58 \pm 0.04$, dissolved oxygen $5.82 \pm 0.21 \mathrm{ppm}$, ammonia values were below of 0.08 $\mathrm{mg} / \mathrm{L}$, alkalinity shows a range between 85 and 95 $\mathrm{mg} / \mathrm{L}$, hardness between 115 and $125 \mathrm{mg} / \mathrm{L}$ and

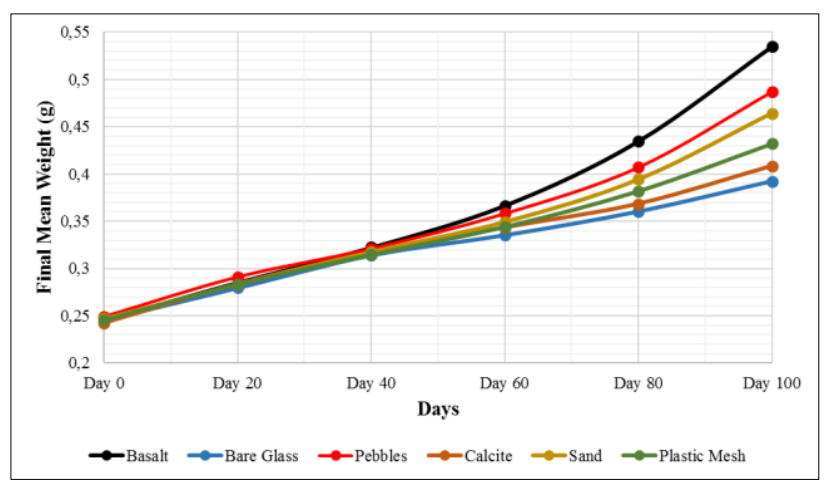

Figure 2. Gain of average body weight $(\mathrm{g})$ of Mexican dwarf orange crayfish during 100 days of substrate experiment. nitrite values were in a range $0-0.02 \mathrm{mg} / \mathrm{L}$. All juveniles significantly $(\mathrm{P}<0.05)$ preferred basalt among the five other substrates (Figure 4). Pebble and sand caused an intermediate effect. Glass, plastic mesh and calcite are the less preferred substrates $(\mathrm{P}<0.05)$

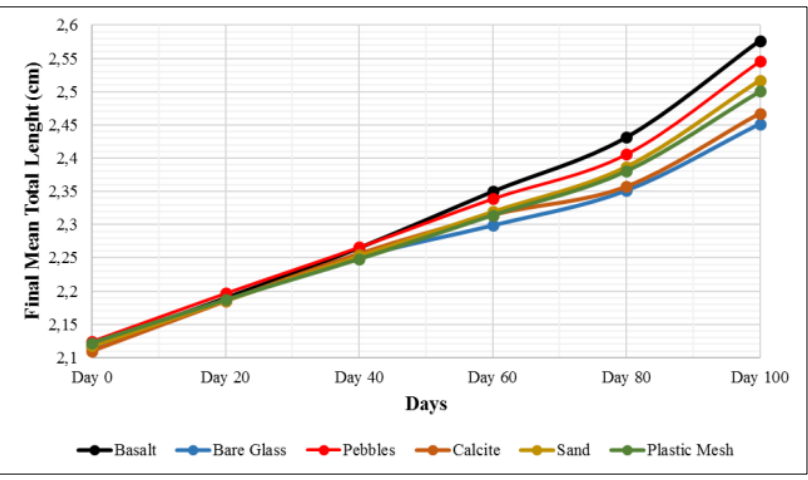

Figure 3. Gain of average total length $(\mathrm{cm})$ of Mexican dwarf orange crayfish during 100 days of substrate experiment.

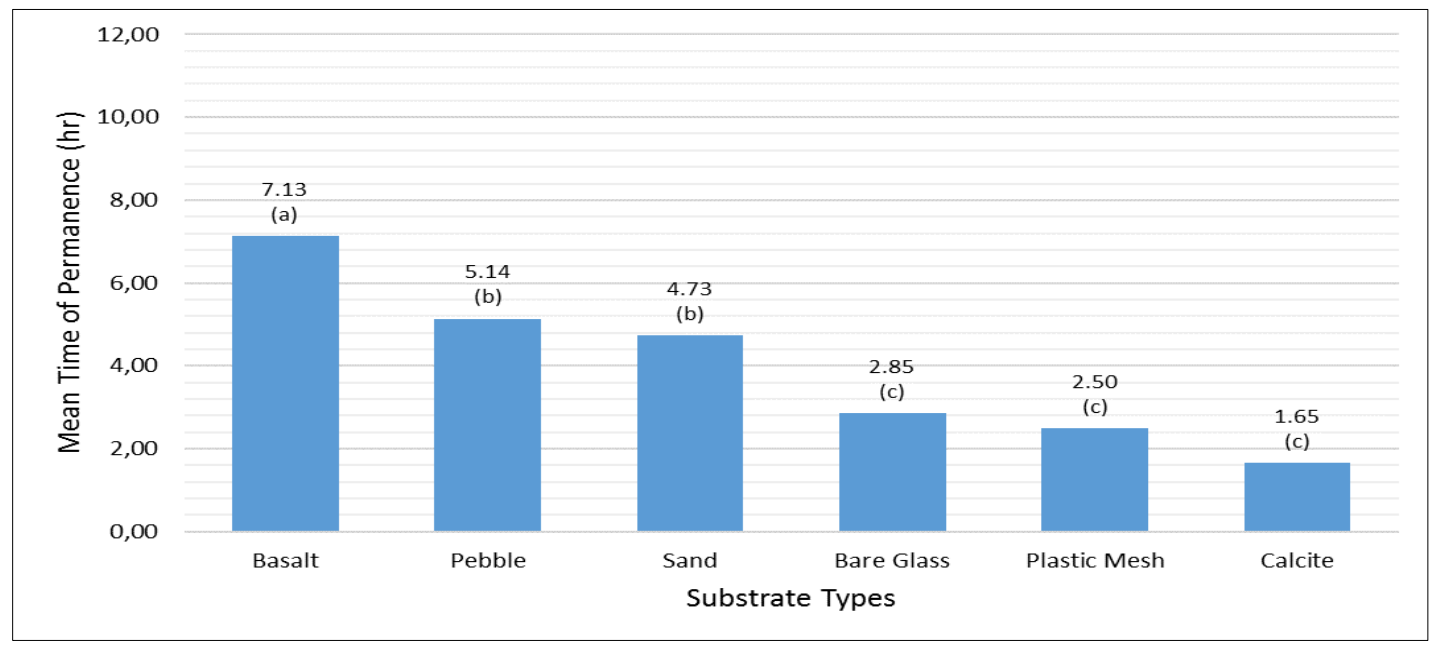

Figure 4. Spending time (h) in each substrate in substrate preference experiment (different letters indicate statistical differences at $5 \%$ among the treatment 


\section{Discussion}

The results of the current growth experiment indicate that Mexican dwarf orange crayfish gained significantly higher weight when raised on basalt substrates. According to result of substrate preference experiment, crayfish spent more time on basalt substrate when given a choice of substrates. These results were pointed that the type of substrate is an important parameter for growth performance and selection of life habitats on this species.

Nocturnal macroinvertebrates like many crayfish can use the substrate as a shelter and hiding area during daytime (Barbaresi et al. 2007). Substrate presence in natural conditions of crayfish is very important factor for growth and other living features. Non-substrated artificial areas or poor sheltering may put the life of crayfish in danger. For example, unwanted situations such as decreasing growth performance and survival rates, harmful behaviours in vulnerable stages (juvenile stages or moulting) and increasing cannibalism can occur. Previous substrate selection studies carried out with different crayfish species such as signal crayfish, Pacifastacus leniusculus (Mason 1978; Savolainen et al. 2003), Australian red claw crayfish, C. quadricarinatus (Viau and Rodríguez 2010), red swamp crayfish, $P$. clarkii (Türkmen and Karadal 2012b) and blue tiger crayfish, Cherax albertisii (Karadal and Türkmen 2014) have clearly showed that crayfish on the bare glass (control) have the lowest growth and survival rate. These findings are supported by results of this present study.

Artificial substrates can be used to increase the growth performance of crayfish. Jones et al. (2002) showed that using synthetic elastic mat as a substrate on juvenile yabby, $C$. destructor was significantly improved some growth parameters, except survival. Nevertheless, synthetic substrates do not always provide advantages. Especially, feeding behaviours was often limited after these substrates were placed in the tanks. For instance, crayfish cannot reach the feed because of they flee under synthetic substrate covered whole bottom of the tanks or aquariums. So, if there is a natural substrate in the medium, the synthetic substrate may not be used. D'Abramo et al. (2006) observed the development of red swamp crayfish in pools with plastic net and natural substrates on the ground. They found that the daily average growth rate of the individuals in the pools with natural substrate was $48 \%$, while plastic net group was $15 \%$. A synthetic substrate (plastic fly mesh) was used in current study and it caused intermediate effect between natural substrates and bare glass on growth performance of Mexican dwarf orange crayfish as seen in Australian red claw crayfish studies by Viau and Rodríguez (2010).
According to Streissl and Hödl (2002), substrate selection affected by distribution and habitat variation. Previous studies have clearly stated that the effects of different substrates may vary species to species. Simon and Cooper (2014) pointed that large species prefer habitats with larger substrate particle size than small crayfish. Especially, juveniles and moulted individuals use substrate as refuge to defend themselves from predation (Jones and Ruscoe 2001; Molony and Bird 2005). Some natural substrate types including gravel, stones, sand and pebble were increased the growth rates of signal crayfish, Australian red claw crayfish, red swamp crayfish and blue tiger crayfish, respectively (Savolainen et al. 2003; Viau and Rodríguez 2010; Türkmen and Karadal 2012b; Karadal and Türkmen 2014). This could be explained by all four substrate types are found in the ecological environment of these crayfish species. Previous studies have stated that the importance of ensuring proper habitats for Australian red claw crayfish during the commercial culture to improve growth performance (Du Boulay et al. 1993; Karplus et al. 1995). Herrnkind and Butler (1986) declared that natural substrates have vital properties on growth performance of both freshwater and marine decapod species. Viau and Rodríguez (2010) noticed that it was feasible that a nutritional or behavioural response to a substrate similar to the one found in nature enhanced the growth of crayfish species. Our results indicated that Mexican dwarf orange crayfish kept in basalt attained higher body weights. Lava sediment overlie lacustrine clays oversaturated with in the Pátzcuaro region (Pola et al. 2014). In nature, this species is found in lava sandy areas (Dost 2013). So that the basalt is close to natural substrate of this species with its small particles and greyish black colour. Our findings for substrate preference of Mexican dwarf orange crayfish were supported by all these earlier researches carried out with various crayfish species.

The results of these experiments show that the natural substrate of Mexican dwarf orange crayfish is very important for their growth and survival. In conclusion, on the purpose of growing, preference and keeping of juvenile this dwarf species in aquarium systems, it is recommended to use of basalt as bottom substrate. However, further studies on the environmental requirements in aquarium systems of Mexican dwarf orange crayfish are needed to decrease aggressive interactions and cannibalism of this poorly known species.

\section{Acknowledgements}

The data used in the present study has formerly been the subject of the master thesis of Onur Karadal prepared in Graduate School of Natural and Applied 
Sciences, Ege University, İzmir, Turkey. Some parts of this study have been presented in Ecology 2017 International Symposium, Kayseri, Turkey as oral and poster presentations on May $11-13^{\text {th }}, 2017$. As the authors, we would like to thank Assoc. Prof. Dr. Hülya Saygı for helping to data analysis.

\section{References}

Alvarez F, López-Mejía M, Pedraza Lara C. 2010. Cambarellus patzcuarensis. The IUCN Red List of Threatened Species. Available from http://www.iucnredlist.org/details/153802/0

APPA 2016. American Pet Products Association; (Access on July 20 ${ }^{\text {th }}$, 2016). Available from http://americanpetproducts.org

Barbaresi S, Cannicci S, Vannini M, Fratini S. 2007. Environmental correlates of two macro-decapods distribution in central Italy: multidimensional ecological knowledge as a tool for conservation of endangered species. Biol Conserv. 136(3):431-441. doi:10.1016/j.biocon.2006.12.013

Chucholl C. 2013. Invaders for sale: trade and determinants of introduction of ornamental freshwater crayfish. Biol Invasions. 15(1):125-141. doi:10.1007/s10530-012-0273-2

D'Abramo LR, Ohs CL, Elgarico KCE. 2006. Effect of added substrate on production of red swamp crawfish (Procambarus clarkii) in earthen ponds without planted forage. J World Aquacult Soc. 37(3):307-312. doi:10.1111/j.1749-7345.2006.00041.x

Dost U. 2013. The orange dwarf crayfish. TFH Magazine, April 2013, pp. 64-67.

Du Boulay AJH, Sayer MDJ, Holdich DM. 1993. Investigations into intensive culture of the Australian red claw crayfish Cherax quadricarinatus. Freshwater Crayfish 9(1):70-78.

Faulkes Z. 2006. Digging mechanisms and substrate preferences of shovel nosed lobsters, Ibacus peronii (Decapoda: Scyllaridae). J Crustacean Biology. 26(1):69-72. doi:10.1651/C-2628.1

Faulkes Z. 2015. Marmorkrebs (Procambarus fallax f. virginalis) are the most popular crayfish in the North American pet trade. Knowl Manag Aquat Ec. 416:20. doi:10.1051/kmae/2015016

Francis DR, Kane TC. 1995. Effect of substrate on colonization of experimental ponds by Chironomidae (Diptera). J Freshwater Ecol. 10(1):57-63.

Herrnkind WF, Butler MJ. 1986. Factors regulating postlarval settlement and juvenile microhabitat use by spiny lobsters Panulirus argus. Mar Ecol Prog Ser. 34(1/2):23-30.

Jones CM, Ruscoe IM. 2001. Assessment of five shelter types in the production of redclaw crayfish Cherax quadricarinatus (Decapada: Parastacidae) under earthen pond conditions. J World Aquacult Soc. 32(1):41-52.

doi:10.1111/j.1749-7345.2001.tb00920.x

Jones PL, Thanuthong T, Kerr P. 2002. Preliminary study on the use of synthetic substrate for juvenile stage production of the yabby, Cherax destructor (Clark)
(Decapoda: Parastacidae). Aquac Res. 33(10):811818.

doi:10.1046/j.1365-2109.2002.00724.x

Karadal O, Türkmen G. 2014. Effects of substrate preference on growth and survival of blue tiger crayfish (Cherax albertisii). EgeJFAS. 31(1):1-4. doi:10.12714/egejfas.2014.31.1.01

Karplus I, Barki A, Levi T, Hulata G, Harpaz S. 1995. Effects of kinship and shelters on growth and survival of juvenile Australian redclaw crayfish (Cherax quadricarinatus). Freshwater Crayfish, 10(1):494505.

Kawai T, Faulkes Z, Scholtz G. 2015. Freshwater Crayfish: A global overview. Florida:CRC Press $679 \mathrm{p}$.

Kusabs IA, Quinn JM, Hamilton DP. 2015. Effects of benthic substrate, nutrient enrichment and predatory fish on freshwater crayfish (kōura, Paranephrops planifrons) population characteristics in seven $\mathrm{Te}$ Arawa (Rotorua) lakes, North Island, New Zealand. Mar Freshwater Res. 66(7):631-643. doi:10.1071/MF14148

Kwang PY, Lee L, Wong A, Lin LY. 2010. Norway's WTO notification on draft regulations relating to the import and release of alien organisms. Ornamental Fish Newsletter, 1(2):2.

Lipták B, Vitázková B. 2015. Beautiful, but also potentially invasive. Ekológia (Bratislava), 34(2):155-162. doi:10.1515/eko-2015-0016

Mason JC. 1978. Effects of temperature, photoperiod, substrate, and shelter on survival, growth, and biomass accumulation of juvenile Pacifastacus leniusculus in culture. Freshwater Crayfish, 4(1):73-82.

Molony BW, Bird C. 2005. Are marron, Cherax tenuimanus (Crustacea: Decapoda), populations in irrigation reservoirs habitat limited? A trial using artificial habitats. Lakes \& Reservoirs: Research \& Management, 10(1):39-50. doi:10.1111/j.1440-1770.2005.00252.x

Papavlasopoulou I. Perdikaris C, Vardakas L, Paschos I. 2014. Enemy at the gates: introduction potential of non-indigenous freshwater crayfish in Greece via the aquarium trade. Cent Eur J Biol. 9(1):11-18. doi:10.2478/s11535-013-0120-6

Patoka J, Kalous L, Kopecký O. 2014. Risk assessment of the crayfish pet trade based on data from the Czech Republic. Biol Invasions. 16(12):2489-2494. doi:10.1007/s10530-014-0682-5

Patoka J, Kalous L, Kopecký O. 2015. Imports of ornamental crayfish: the first decade from the Czech Republic's perspective. Knowl Manag Aquat Ec. 416:04. doi:10.1051/kmae/2014040

Peay S, Holdich DM, Brickland J. 2010. Risk assessments of non-indigenous crayfish in Great Britain. Freshwater Crayfish, 17(1):109-122.

PFMA 2016. Pet Food Manufacturers' Association; (Access on July 20 $0^{\text {th }}, 2016$ ). Available from http://www.pfma.org.uk

Pola A, Macías JL, Garduño-Monroy VH, Osorio-Ocampo S, Cardona-Melchor S. 2014. Successive collapses of 
the El Estribo volcanic complex in the Pátzcuaro Lake, Michoacán, Mexico. J Volcanol Geoth Res. 289:4150 . doi:10.1016/j.jvolgeores.2014.10.011

Pottern G. 2007. Mexican dwarf orange crayfish, Cambarellus patzcuarensis. The Raleigh Aquarium Society Monthly Feature, May 2007, pp. 23.

Rohmann U. 2010. Cambarellus patzcuarensis sp. orange. PRAC Publication, Hi-Fin, February 2010, pp. 5-6.

Savolainen R, Ruohonen K, Tulonen J. 2003. Effects of bottom substrate and presence of shelter in experimental tanks on growth and survival of signal crayfish, Pacifastacus leniusculus (Dana) juveniles. Aquac Res. 34(4):289-297. doi:10.1046/j.1365-2109.2003.00817.x

Simon TP, Cooper NJ. 2014. Habitat suitability index relationships for the northern clearwater crayfish, Orconectes propinquus (Decapoda: Cambaridae). Fisheries and Aquaculture Journal, 5(3):1-7. doi:10.4172/2150-3508.100098

Streissl F, Hödl W. 2002. Habitat and shelter requirements of the stone crayfish, Austropotamobius torrentium Schrank. Hydrobiologia. 477(1-3):195-199. doi:10.1023/A:1021094309738
Türkmen G, Karadal O. 2012a. The survey of the imported freshwater decapod species via the ornamental aquarium trade in Turkey. $\mathbf{J}$ Anim Vet Adv. 11(15):2824-2827. doi:10.3923/javaa.2012.2824.2827

Türkmen G, Karadal O. 2012b. Substrate preference on juvenile red swamp crayfish (Procambarus clarkii). EgeJFAS. 29(2):73-76.

Türkmen G, Karadal O. 2015. Crayfish species exhibited in aquarium sector of Turkey. Paper presented at: $18^{\text {th }}$ National Fisheries Symposium İzmir, Turkey.

Viau VE, Rodríguez EM. 2010. Substrate selection and effect of different substrates on survival and growth of juveniles of the freshwater crayfish Cherax quadricarinatus (von Martens 1868) (Decapoda, Parastacidae). Aquacult Int. 18(5):717-724. doi:10.1007/s10499-009-9292-0

Zar JH. 2001. Biostatistical analysis, $4^{\text {th }}$ edn. Upper Saddle River:Prentice-Hall Inc., 929 p.

Zimmermann BL, Dambros CS, Santos S. 2016. Association of microhabitat variables with the abundance and distribution of two neotropical freshwater decapods (Anomura: Brachyura). J Crustacean Biol. 36(2):198-204. doi:10.1163/1937240X-00002408 